Re-submitted to:

Date:
Water Research

January 31,2005

(\#04-311)

\title{
Reaction Pathways and Mechanisms of the Electrochemical Degradation of Phenol on Different Electrodes
}

\author{
Xiao-yan Li ${ }^{a^{*}}$, Yu-hong Cui ${ }^{b}$, Yu-jie Feng ${ }^{b}$, Zhao-ming Xie ${ }^{a}$ and Ji-Dong Gu ${ }^{c}$ \\ ${ }^{a}$ Environmental Engineering Research Centre, Department of Civil Engineering, \\ The University of Hong Kong, Pokfulam Road, Hong Kong, China \\ ${ }^{\mathrm{b}}$ Department of Environmental Science and Engineering, Harbin Institute of Technology, \\ Nangang District, Harbin, 150090, China \\ ${ }^{\mathrm{c}}$ Department of Ecology and Biodiversity, The University of Hong Kong, Pokfulam Road, \\ Hong Kong, China
}

$\begin{array}{lll}* \text { Corresponding Author: } & \text { Phone: } & (852) \text { 2859-2659 } \\ & \text { Fax: } & (852) 2559-5337 \\ & \text { E-mail: } & \text { xlia@hkucc.hku.hk }\end{array}$

Running head: Electrochemical phenol degradation. 


\begin{abstract}
Laboratory experiments were carried out on the kinetics and pathways of the electrochemical (EC) degradation of phenol at three different types of anodes, $\mathrm{Ti} / \mathrm{SnO}_{2}-\mathrm{Sb}, \mathrm{Ti} / \mathrm{RuO}_{2}$, and $\mathrm{Pt}$. Although phenol was oxidised by all of the anodes at a current density of $20 \mathrm{~mA} / \mathrm{cm}^{2}$ or a cell voltage of $4.6 \mathrm{~V}$, there was a considerable difference between the three anode types in the effectiveness and performance of EC organic degradation. Phenol was readily mineralized at the $\mathrm{Ti} / \mathrm{SnO}_{2}-\mathrm{Sb}$ anode, but its degradation was much slower at the $\mathrm{Ti} / \mathrm{RuO}_{2}$ and $\mathrm{Pt}$ anodes. The analytical results of high performance liquid chromatography (HPLC) and gas chromatography coupled with mass spectrometry (GC/MS) indicated that the intermediate products of EC phenol degradation, including benzoquinone and organic acids, were subsequently oxidised rapidly by the $\mathrm{Ti} / \mathrm{SnO}_{2}-\mathrm{Sb}$ anode, but accumulated in the cells of $\mathrm{Ti} / \mathrm{RuO}_{2}$ and Pt. There was also a formation of dark-ed polymeric compounds and precipitates in the solutions electrolyzed by the $\mathrm{Ti} / \mathrm{RuO}_{2}$ and $\mathrm{Pt}$ anodes, which was not observed for the $\mathrm{Ti} / \mathrm{SnO}_{2}-\mathrm{Sb}$ cells. It is argued that anodic property not only affects the reaction kinetics of various steps of EC organic oxidation, but also alters the pathway of phenol electrolysis. Favourable surface treatment, such as the $\mathrm{SnO}_{2}-\mathrm{Sb}$ coating, provides the anode with an apparent catalytic function for rapid organic oxidation that is probably brought about by hydroxyl radicals generated from anodic water electrolysis.
\end{abstract}

\title{
Keywords:
}

Anode; electrochemistry; electro-oxidation; free radicals; phenol; wastewater treatment. 


\section{Introduction}

Aromatic compounds are common pollutants in the waste effluent from many industrial sectors, such as petroleum refineries, synthetic chemical plants, plastics, pulp and paper, textiles, detergent, pesticide and herbicide, and pharmaceutical factories. Wastewater containing aromatic chemicals is refractory, and is often toxic to biological treatment processes. Attempts have been made to degrade and destroy aromatic organics using various advanced oxidation processes (AOPs), including photochemical reactions, Fenton oxidation, ozonation, and supercritical water oxidation $[1,2]$. Electrochemistry is another alternative that has attracted considerable research attention [3-5]. Toxic organics can be effectively oxidised by electrochemical (EC) reaction [5-9]. With unique features such as simplicity and robustness in structure and operation, the EC process has the potential to be developed as a cost-effective technology for the treatment of aromatic pollutants, particularly for lowvolume applications.

The effectiveness of EC wastewater treatment depends on the nature of the anodes that are used in the process [9-11]. Traditional electrodes, such as graphite and nickel, show a poor current efficiency in organic degradation [4]. Dimensionally stable anodes (DSAs) that are prepared by the deposition of a thin layer of metal oxides on a base metal, usually titanium, are found to have a varying degree of success. The widely used $\mathrm{RuO}_{2}$ and $\mathrm{IrO}_{2}$ based coating surface does not appear to have a high reactivity for organic oxidation $[3,9,12]$. Other DSA coating materials, such as $\mathrm{PbO}_{2}$ and $\mathrm{SnO}_{2}$-based coatings, have been introduced to improve the treatment performance. $\mathrm{PbO}_{2}$ electrodes can be highly effective for complete organic destruction, e.g., EC incineration [3,13-15]. Hence, $\mathrm{PbO}_{2}$ and similar anodes are considered to be of sufficient electro-catalytic capacity for organic oxidation $[3,9,16-18]$. However, concern over the possible toxicity of $\mathrm{Pb}$ leaching from the working anode would hinder the actual application of $\mathrm{PbO}_{2}$ electrodes. The $\mathrm{SnO}_{2}$-based coating has shown a similar 
reactivity as that of $\mathrm{PbO}_{2}$ for $\mathrm{EC}$ organic degradation $[4,6,19,20]$. With further development and characterization, $\mathrm{SnO}_{2}$ anodes are expected to offer a better solution for the enhancement and application of the EC process to organic degradation.

The difference in the effectiveness and performance of different anode materials for wastewater treatment demonstrates the complexity of the EC reaction mechanisms involved. It has been reported that the oxidation of phenol can stop with such products as maleic acid and oxalic acid for Pt anodes [21,22]. However, complete phenol oxidation can be achieved for $\mathrm{PbO}_{2}$ electrodes $[9,15,24]$. Hence, the degradation pathway of aromatic organics on different anodes remains a subject for investigation. It is unclear whether the anode surface property would affect the reaction kinetics or alter the pathway of organic oxidation. In the present laboratory study, phenol, which is the basic unit of aromatic compounds, was used as the model organic for $\mathrm{EC}$ degradation. Ti anodes coated with $\mathrm{SnO}_{2}$ and doped with $\mathrm{Sb}$ $\left(\mathrm{Ti} / \mathrm{SnO}_{2}-\mathrm{Sb}\right)$ were examined for their performance in EC phenol degradation and compared to the $\mathrm{Ti}$ anodes coated with $\mathrm{RuO}_{2}\left(\mathrm{Ti} / \mathrm{RuO}_{2}\right)$ and the Pt anodes. The intermediate products of the EC treatment process with different anodes were measured to determine the phenol degradation pathways and related reaction mechanisms.

\section{Materials and Methods}

\subsection{Electrode Preparation}

Three types of electrodes, $\mathrm{Ti} / \mathrm{SnO}_{2}-\mathrm{Sb}, \mathrm{Ti} / \mathrm{RuO}_{2}$, and $\mathrm{Pt}$, were used as anodes for the phenol oxidation study. The $\mathrm{Ti} / \mathrm{SnO}_{2}-\mathrm{Sb}$ anode was selected because of its expected electrocatalytic function for organic oxidation $[6,10,20], \mathrm{Ti} / \mathrm{RuO}_{2}$ is one of the most widely used DSA electrodes, and Pt is a common material in electrochemistry studies. The Ti plates (99.5\%) were rectangular in shape with a dimension of $2 \times 3 \mathrm{~cm}^{2}$ and a thickness of $1.5 \mathrm{~mm}$. 
They were polished thoroughly with a 320 -grit sandpaper, and then degreased in $40 \% \mathrm{NaOH}$ at $80^{\circ} \mathrm{C}$ for $2 \mathrm{hrs}$ and etched in $15 \%$ oxalic acid at $98^{\circ} \mathrm{C}$ for $2 \mathrm{hrs}$, followed by a thorough washing with de-ionized (DI) water. The treated Ti plates became grey, losing their metallic sheen.

The $\mathrm{Ti} / \mathrm{RuO}_{2}$ electrodes were prepared by the thermal deposition of $\mathrm{RuO}_{2}$ on the $\mathrm{Ti}$ plates following the procedure described elsewhere $[8,9,25]$. Briefly, a fully polished Ti plate was dipped into a coating solution that consisted of $0.5 \mathrm{M} \mathrm{RuCl}_{3}$ (Aldrich) in n-butanol (99+\%, Aldrich) with $10 \%$ by volume of concentrated $\mathrm{HCl}(37 \%)$. The wet coating surface was dried in an oven at $60^{\circ} \mathrm{C}$ for $30 \mathrm{~min}$. After repeating the dipping and drying ten times, the Ti plate was heated in airflow at an annealing temperature of $450^{\circ} \mathrm{C}$ in a muffle oven for $1 \mathrm{hr}$. The above procedure was repeated three times to produce the $\mathrm{Ti} / \mathrm{RuO}_{2}$ anodes.

The $\mathrm{Ti} / \mathrm{SnO}_{2}-\mathrm{Sb}$ electrodes were prepared by electro-deposition for the inner coating layer and thermal deposition for the outer layer, which is a procedure modified from methods described by others $[6,19,26]$. For electro-deposition, a Ti plate was placed as the cathode in $100 \mathrm{ml}$ of alcohol solution containing $17.5 \mathrm{~g} \mathrm{SnCl}_{4} \cdot 5 \mathrm{H}_{2} \mathrm{O}$ (Aldrich), $0.73 \mathrm{~g} \mathrm{Sb}_{2} \mathrm{O}_{3}$ (Aldrich), and $2 \mathrm{ml}$ concentrated $\mathrm{HCl}(37 \%)$. A constant DC current of $0.12 \mathrm{~A}$ was charged for 25 mins for electroplating the cathode, and Pt was used as the counter electrode. The inner coating layer on the Ti plate was dried in an oven at $400^{\circ} \mathrm{C}$ for $2 \mathrm{hrs}$. For the thermal deposition of the outer layer, the Ti plate was dipped into a coating solution that consisted of $30 \mathrm{~g} \mathrm{SnCl}_{4} \cdot 5 \mathrm{H}_{2} \mathrm{O}$, $0.8 \mathrm{~g} \mathrm{Sb}_{2} \mathrm{O}_{3}$ and $2.5 \mathrm{ml}$ concentrated $\mathrm{HCl}(37 \%)$ in $50 \mathrm{ml} \mathrm{n}$-butanol. After five dipping-drying cycles at an ambient temperature, the Ti plate was annealed in a muffle oven at $550^{\circ} \mathrm{C}$ for 2 hrs. The above procedure was repeated five times to produce the $\mathrm{Ti} / \mathrm{SnO}_{2}-\mathrm{Sb}$ electrodes. The inner electroplating on the Ti plates was found to be essential for the improvement of the durability and stability of the $\mathrm{SnO}_{2}$-Sb coating surface on the Ti anodes. 
The electrodes $\left(1 \times 1 \mathrm{~cm}^{2}\right)$ were examined for their cyclic voltammetry $(\mathrm{CV})$ by a computer-controlled potentiostat/galvanostat (Model 263, EG\&G) using a three-electrode cell, with stainless steel as the counter electrode and the standard $\mathrm{Ag} / \mathrm{AgCl}$ electrode (Cypress System) as the reference electrode.

\subsection{Phenol Electrolysis}

EC phenol degradation was conducted in batch electrolysis cells that were 100-ml glass beakers, each with a cover cap with two open slits for assembling the electrodes. In combination with the working anodes described above, stainless steel plates of the same size $\left(2 \times 3 \mathrm{~cm}^{2}\right)$ were used as the cathodes. The two electrodes in each cell were placed $8 \mathrm{~mm}$ apart and facing each other. A DC potentiostat was employed as the power supply with a voltage output up to $20 \mathrm{~V}$.

For an electrolysis test, $80 \mathrm{ml}$ of a phenol solution of a predetermined concentration (100 or $490 \mathrm{mg} / \mathrm{L}$ ) was placed in the cell with $0.25 \mathrm{M} \mathrm{Na}_{2} \mathrm{SO}_{4}$ as the electrolyte. A consistent DC current of 0.12 A was charged to the pair of electrodes, which resulted in a current intensity of $20 \mathrm{~mA} / \mathrm{cm}^{2}$. As an alternative, the same voltage of $4.6 \mathrm{~V}$ was supplied to the three different cells of the $\mathrm{Ti} / \mathrm{SnO}_{2}-\mathrm{Sb}, \mathrm{Ti} / \mathrm{RuO}_{2}$, and $\mathrm{Pt}$ anodes. The EC cells were placed on a magnetic stirrer for continuous mixing, and the temperature stayed at around $25^{\circ} \mathrm{C}$ without special control measures. Samples were withdrawn from the electrolyzed solutions at various intervals for chemical analysis of the phenol, the total organic carbon (TOC), and intermediate products.

\subsection{Analytical Methods}

All chemicals were of reagent grade, and all water solutions were prepared by DI water. The TOC was measured by a TOC analyzer (5000A, Shimadzu) based on the combustion- 
infrared method. The solution $\mathrm{pH}$ was recorded by a $\mathrm{pH}$ meter (420A, Orion). High performance liquid chromatography (HPLC) was used to analyze the phenol and the aromatic intermediate compounds from the EC phenol degradation, including benzoquinone and hydroquinone [27,28]. The HPLC (Agilent 1100) was equipped with a Zorbax column (Eclipse XDB-C8, ID $=4.6 \mathrm{~mm}$, length $=150 \mathrm{~mm}$, Agilent) and a UV detector used at working wavelengths of 212, 245, 260, and $290 \mathrm{~nm}$. Methanol/water $=1 / 4(\mathrm{~V} / \mathrm{V})$ was used as the mobile phase at a flow rate of $0.9 \mathrm{ml} / \mathrm{min}$. Before each analysis, the sample was filtered through a $0.2-\mu \mathrm{m}$ membrane filter (Osmonics). The injection volume was $50 \mu 1$.

Gas chromatography (GC) and gas chromatography coupled with mass spectrometry (GC/MS) were used for the measurement of the organic acids that were produced by the phenol electrolysis. To allow GC measurement of the non-volatile organic acids, the samples were esterified and then extracted following the procedure described elsewhere [29-31]. Esterification was performed by adding $3 \mathrm{ml}$ of a sample and $2 \mathrm{ml}$ of $\mathrm{n}$-butanol together with $2 \mathrm{ml}$ of concentrated $\mathrm{HCl}(37 \%)$ as catalyst in a $40-\mathrm{ml}$ sealed bottle. The mixed solution was heated at $75^{\circ} \mathrm{C}$ for $40 \mathrm{~min}$. After cooling, $6 \mathrm{ml}$ of hexane (HPLC grade, Fisher) was used to extract the esterified products from the solution. The extraction was repeated twice, and the extracted liquid was concentrated to $1 \mathrm{ml}$ by a nitrogen flow before $\mathrm{GC}$ analysis. The GC (HP6890, Agilent) used a capillary column (HP-624, $25.0 \mathrm{~m} \times 200 \mu \mathrm{m} \times 1.12 \mu \mathrm{m}$, Agilent) followed by detection with an MS (Netwaik 5973, Agilent). The temperature program began at $70^{\circ} \mathrm{C}$ and increased at a rate of $20^{\circ} \mathrm{C} / \mathrm{min}$ up to $230^{\circ} \mathrm{C}$, with a holding time of $2 \mathrm{~min}$ for each increment. Helium was used as the carrier gas at a constant flow rate of $53.6 \mathrm{ml} / \mathrm{min}$. The samples were injected in the splitless mode, and each injection was $1 \mu$ l. For quantification of a number of the intermediate organic acids, including maleic acid, succinic acid, and oxalic acid, another GC (HP6890, Agilent) equipped with a capillary column (HP4, $30.0 \mathrm{~m} \times 320 \mu \mathrm{m} \times 0.25 \mu \mathrm{m}$, Agilent) and a flame ionization detector (FID) was used. The 
temperature was increased from $70^{\circ} \mathrm{C}$ at $10^{\circ} \mathrm{C} / \mathrm{min}$ up to $180^{\circ} \mathrm{C}$ and then at $40^{\circ} \mathrm{C} / \mathrm{min}$ up to $260^{\circ} \mathrm{C}$ with a holding time of $2 \mathrm{~min}$ for each increment. The helium carrier gas had a flow rate of $13.7 \mathrm{ml} / \mathrm{min}$, and the sample injection procedure was the same as that described previously.

\section{Results and Discussion}

\subsection{Performance of Selected Anodes on Phenol Degradation}

The three types of anodes, $\mathrm{Ti} / \mathrm{SnO}_{2}-\mathrm{Sb}, \mathrm{Ti} / \mathrm{RuO}_{2}$, and $\mathrm{Pt}$, performed considerably differently in the EC phenol degradation (Fig. 1A). The best result was obtained with the $\mathrm{Ti} / \mathrm{SnO}_{2}-\mathrm{Sb}$ anode, followed by the $\mathrm{Pt}$ anode and then the $\mathrm{Ti} / \mathrm{RuO}_{2}$ anode, although complete phenol removal was achieved by all of the anodes. The phenol was oxidised rapidly by the $\mathrm{Ti} / \mathrm{SnO}_{2}-\mathrm{Sb}$ anode, as its concentration decreased from around $490 \mathrm{mg} / \mathrm{L}$ to zero after $5 \mathrm{hrs}$ of electrolysis. At the same current input rate on the other two anodes the rates of phenol degradation were much slower. The time for complete phenol removal extended to about 18 hrs for the Pt anode and $36 \mathrm{hrs}$ for the $\mathrm{Ti} / \mathrm{RuO}_{2}$ anode.

The three anode types had an even greater difference in the effectiveness of TOC removal (Fig. 1B). On the $\mathrm{Ti} / \mathrm{SnO}_{2}-\mathrm{Sb}$ anode, complete organic mineralization was achieved within 16 hrs. However, under the same current conditions with the $\mathrm{Ti} / \mathrm{RuO}_{2}$ and $\mathrm{Pt}$ anodes only $40 \%$ or less of the TOC was removed after a long treatment period of $48 \mathrm{hrs}$. The reproducibility of the EC experiments in terms of phenol and TOC degradation was satisfactory for each type of anode tested, with a low degree of variation observed in repeated test runs (Fig. 1). For the same voltage input of $4.6 \mathrm{~V}$ to the electrolysis cells, a different performance in phenol degradation was also recorded for the three different electrodes. With 
the $\mathrm{Ti} / \mathrm{SnO}_{2}-\mathrm{Sb}$ anode, a much lower charge consumption was used to achieve complete phenol and TOC removal than was used with the $\mathrm{Ti} / \mathrm{RuO}_{2}$ and $\mathrm{Pt}$ anodes.

The residual TOC in the solutions after phenol removal suggests the formation and accumulation of intermediate organic products, particularly with the $\mathrm{Pt}$ and $\mathrm{Ti} / \mathrm{RuO}_{2}$ anodes. The solution $\mathrm{pH}$ also changed during the electrolysis process (Fig. 1C). The $\mathrm{pH}$ dropped from the initial value of 5.3 to below 4.0 while the phenol was being electrochemically oxidised. It remained at around 3.5 with no sign of rising in the solutions that were treated by the $\mathrm{Pt}$ and $\mathrm{Ti} / \mathrm{RuO}_{2}$ anodes. In the $\mathrm{Ti} / \mathrm{SnO}_{2}-\mathrm{Sb}$ system, the $\mathrm{pH}$ began to increase after the phenol disappeared from the solution. The $\mathrm{pH}$ approached 7 when the TOC was completely removed after 16 hrs of electrolysis. The drop in $\mathrm{pH}$ was apparently caused by the formation of acidic substances from the phenol degradation. In combination with the TOC results, organic acids were probably one of the main intermediates produced by phenol electrolysis $[3,9,14,18,21]$.

\subsection{Intermediate Products}

The phenol solutions also exhibited colour changes during the electrolysis process. In the $\mathrm{Ti} / \mathrm{SnO}_{2}-\mathrm{Sb}$ cells, the liquid turned to yellow in the first $5 \mathrm{hrs}$ of phenol oxidation. The yellow colour began to fade when the phenol concentration was reduced to zero, and the colour had almost disappeared about $4 \mathrm{hrs}$ before the TOC was completely removed. For the $\mathrm{Pt}$ and $\mathrm{Ti} / \mathrm{RuO}_{2}$ anodes, however, the solution became dark yellow and turned to brown when the phenol had been totally removed. The colour did not fade even after another 24 hrs of electrolysis. It is generally believed that the yellow colour is caused by benzoquinone, which is produced by phenol oxidation [21]. The accumulation of benzoquinone was well detected by HPLC for the phenol solutions treated by all three types of anodes (Fig. 2). Hydroquinone, which is colourless, was found in an even higher quantity in all the experiments. Benzoquinone and hydroquinone are known as an active redox couple in equilibrium in an 
aqueous solution [32]. Their fractionation depends mainly on $\mathrm{pH}$ and other aquatic chemistry conditions [27]. The HPLC results indicate the transformation of the phenol by electrolysis to benzoquinone and hydroquinone, which were then both decomposed to other forms. Benzoquinone and hydroquinone were accumulated at a higher concentration level and for a much longer time in the solutions electrolyzed by the $\mathrm{Ti} / \mathrm{RuO}_{2}$ and $\mathrm{Pt}$ anodes than that electrolyzed by the $\mathrm{Ti} / \mathrm{SnO}_{2}$-Sb anode (Fig. 2).

Several carboxylic acids with two, three, and four carbon atoms were identified by GC/MS as important intermediates in the electrolyzed solutions, with maleic acid, succinic acid, and oxalic acid being found in dominant abundance. To quantify these non-volatile organic acids, the samples were esterified and extracted prior to GC determination. The results are presented only as the apparent concentrations in relation to the standards (100 $\mathrm{mg} / \mathrm{L})$ of the respective acids $[29,33,34]$. In a comparative sense, however, there are notable differences between the three EC systems of different anodes in the formation and degradation of the intermediate organic acids. Oxalic acid was the main intermediate product with the $\mathrm{Ti} / \mathrm{SnO}_{2}-\mathrm{Sb}$ anode, and only a small quantity of maleic acid and succinic acid was detected (Fig. 2A). In agreement with the TOC data given in Fig. 1B, the organic acids were completely removed by electrolysis on the $\mathrm{Ti} / \mathrm{SnO}_{2}-\mathrm{Sb}$ anode. For the $\mathrm{Ti} / \mathrm{RuO}_{2}$ and $\mathrm{Pt}$ anodes, however, there was a greater accumulation of maleic acid and succinic acid during the EC process. The overall degradation of the organic acids by these two anodes was much slower than with the $\mathrm{Ti} / \mathrm{SnO} 2-\mathrm{Sb}$ anode under the same experimental conditions.

As described above, a dark yellow to brown colour built up in the solutions that were treated by the $\mathrm{Ti} / \mathrm{RuO}_{2}$ and $\mathrm{Pt}$ anodes. Attempts using the HPLC to identify the substances that caused the colour failed to produce any sensible results. However, according to previous investigations, the colour is probably caused by the polymeric compounds produced by the EC oxidation of phenol [22,35]. The products of polymerization are so-called "synthetic 
humic acids" that consist of hydroquinone-benzoquinone monomeric units and that generally exhibit a dark brown colour [16]. These amorphous polymers are formed by a radical reaction mechanism by phenate anions $[4,36]$. With the $\mathrm{Ti} / \mathrm{RuO}_{2}$ and $\mathrm{Pt}$ anodes, in addition to the brown build-up in the solutions, there were dark precipitates that were probably also formed by the polymeric compounds. For the $\mathrm{Ti} / \mathrm{SnO}_{2}-\mathrm{Sb}$ system, however, only a light yellow colour was visible during the EC process, which disappeared well before the TOC had been completely removed.

\subsection{Pathways and Mechanisms of EC Phenol Degradation}

The mechanism of phenol degradation by EC oxidation has been the subject of several investigations $[4,9,21-23,37,38]$. It is generally considered that phenol oxidation begins with an electron transfer that leads to phenoxy radical reactions [37]. Possible reactions related to phenoxy radicals include radical-radical coupling, radical disproportionation, radical elimination, and radical oxidation of cations. Radical reactions result in the formation of benzoquinone, which is believed to be an important intermediate of phenol oxidation $[17,21,38]$. In the subsequent stage, benzoquinone can be degraded with ring breakage to various carboxylic acids. Several mechanisms have been proposed for benzoquinone degradation. If benzoquinone is adsorbed onto the anode surface and gives up an electron, then the carbon that is double-bonded with the oxygen will be attacked by a neighbouring hydroxyl radical generated from water electrolysis. When this process is repeated at the para position, the ring could be opened and the benzoquinone would be broken down into small organic molecules such as carboxylic acids [14,37]. It has been suggested that the ring cleavage would result in the formation of maleic acid and another small organic compound such as ethene [14]. The intermediate maleic acid has been experimentally proven $[8,14,21]$. With continuous electrolysis, maleic acid would first be reduced to succinic acid at the 
cathode, followed by oxidation at the anode to malonic acid and then to acetic acid, and finally to $\mathrm{CO}_{2}[8,9,14,38]$.

The present experimental findings in the removal of phenol and TOC, and in the formation of intermediate products, are in general agreement with the hypothesized reaction pathway of EC phenol degradation outlined above. Nonetheless, this pathway is apparently inadequate to explain the major differences between the three anodes in treating phenol under a similar EC condition. The theory would have considerable difficulties in accounting for the laboratory observations if the same reaction pathway were assumed for different anodes, including the much faster reaction kinetics with the $\mathrm{Ti} / \mathrm{SnO}_{2}-\mathrm{Sb}$ anode, the formation of oxalic acid, particularly in the liquid electrolyzed by the $\mathrm{Ti} / \mathrm{SnO}_{2}-\mathrm{Sb}$ anode, and the dark coloured polymeric products in the $\mathrm{Ti} / \mathrm{RuO}_{2}$ and $\mathrm{Pt}$ systems. Hence, the EC phenol degradation pathway theory needs to be modified to reconcile it with the experimental observations, although the main routes of the pathway can still be followed.

The major steps of the reaction pathway for EC phenol degradation are summarized in Fig. 3 with an emphasis on two modifications. The first is the inclusion of polymerization via phenoxy radicals that attack either benzoquinone or hydroquinone. Polymerization is hardly a reversible reaction, and the polymeric products are likely to be more recalcitrant to EC degradation than phenol. For benzoquinone and hydroquinone, ring cleavage (I) and polymerization (II) are two parallel processes that occur simultaneously. If the aromatic ring is broken rapidly, then there is little accumulation of benzoquinone and an insignificant formation of polymeric compounds, which is the case with the $\mathrm{Ti} / \mathrm{SnO}_{2}-\mathrm{Sb}$ anode. In contrast, if ring cleavage is rather slow, then polymerization becomes more significant, which is in fact the case with the $\mathrm{Ti} / \mathrm{RuO}_{2}$ and $\mathrm{Pt}$ anodes. Another pathway modification is the addition of a route from maleic acid to oxalic acid $\left(\mathrm{III}_{\mathrm{B}}\right)$ in parallel with the conventional route of maleic acid reduction to succinic acid $\left(\mathrm{III}_{\mathrm{A}}\right)$. For the $\mathrm{Ti} / \mathrm{RuO}_{2}$ and $\mathrm{Pt}$ systems, although the oxidation 
of maleic acid to oxalic acid might also take place, route $\mathrm{III}_{\mathrm{A}}$ is still the dominant process. With the $\mathrm{Ti} / \mathrm{SnO}_{2}-\mathrm{Sb}$ anode, maleic acid is rapidly converted to oxalic acid following route $\mathrm{III}_{\mathrm{B}}$, whereas route $\mathrm{III}_{\mathrm{A}}$ is relatively slower and hence less important. The intermediate oxalic acid is readily oxidised by anodic oxidation to $\mathrm{CO}_{2}[9]$.

The experimental results suggest that EC phenol oxidation on different anodes may follow different reaction pathways. It is apparent that different anode surfaces have different degrees of reactivity towards phenol degradation and its intermediate products. The exact catalytic role of the anode surface in organic oxidation is still under discussion. It is generally believed that organic compounds in aqueous solutions can be oxidised on an anode by direct electron transfer and indirect oxygen atom transfer $[4,7,20,38,39]$. In the direct electron transfer process, organics are adsorbed on the anode surface and give up electrons to the anode, i.e.,

$$
(\text { Organic })_{\text {ads }}-\text { ne }^{-} \rightarrow \text { Product }
$$

With the indirect oxygen atom transfer, it is generally considered that oxygen radicals, especially the hydroxyl radicals generated from water electrolysis, play a critical role in the EC oxidation mechanism of organic substances $[3,25,38,40]$. The formation of hydroxyl radicals on the anode surface can be expressed by Eq. (2), where M stands for the anode $[3,40]$.

$$
\mathrm{M}+\mathrm{H}_{2} \mathrm{O} \rightarrow \mathrm{M}\left[\cdot \mathrm{OH}^{-}\right]+\mathrm{H}^{+}+\mathrm{e}^{-} .
$$

The hydroxyl radicals readily react with the organic molecules adsorbed on or in the vicinity of the anode to cause the oxidation reaction given below

$$
\mathrm{M}\left[\cdot \mathrm{OH}^{-}\right]+\text {Organic } \rightarrow \text { Product } .
$$

Meanwhile, the hydroxyl radicals will react with each other to form molecular oxygen to complete the electrolysis of the water molecules $[3,40]$, i.e.,

$$
2 \mathrm{M}\left[\cdot \mathrm{OH}^{-}\right] \rightarrow 2 \mathrm{M}+\mathrm{O}_{2}+2 \mathrm{H}^{+}+2 \mathrm{e}^{-} .
$$


In organic wastewater treatment, anodic oxygen evolution actually causes a power loss, which reduces the overall current efficiency for both direct and indirect organic oxidation. Therefore, the use of an anode material with a high oxygen evolution potential is especially desirable since it can decrease the unwanted power loss to oxygen generation $[6,10]$. According to the cyclic voltammograms (Fig. 4), the $\mathrm{Pt}$ and $\mathrm{Ti} / \mathrm{RuO}_{2}$ anodes had a lower oxygen evolution potential, with values of 1.4 and $1.1 \mathrm{~V}$ (vs the standard $\mathrm{Ag} / \mathrm{AgCl}$ ), respectively. The $\mathrm{Ti} / \mathrm{SnO}_{2}-\mathrm{Sb}$ anode, however, had a potential of $1.6 \mathrm{~V}$. The high overpotential of the $\mathrm{Ti} / \mathrm{SnO}_{2}-\mathrm{Sb}$ anode suggests that the radical reaction forming molecular oxygen in Eq. (4) was probably restrained, which was favourable to organic oxidation by hydroxyl radicals. Hence, the difference in the oxygen evolution potential for the different anodes could have forced the EC phenol degradation through different pathways (Fig.3).

Aromatic ring opening and maleic acid oxidation represent two limiting steps to complete EC phenol degradation. The high overpotential of the $\mathrm{Ti} / \mathrm{SnO}_{2}$-Sb anode would effectively extend the lifetime of the hydroxyl radicals on the anode, thus permitting more oxygen transfer from the radicals to the organic matter for oxidation (Eq. (3)). Without the strong oxidising power of free radicals, hydroquinone and benzoquinone would accumulate in the system, leading to the formation of polymeric products that are more refractory to EC oxidation. The generation of hydroxyl radicals would provide a sufficient non-selective oxidising capacity that could attack the aromatic rings more effectively and cause ring brokerage. As a result, the reaction step I would be enhanced and step II became less important. For the degradation of maleic acid, the formation of succinic acid by reduction is expected under normal circumstances $[8,9,13,35]$. However, with sufficient hydroxyl radicals formed on the anode, maleic acid could be oxidised directly to oxalic acid, which can be oxidised readily to $\mathrm{CO}_{2}$. As a result, the reaction route $\mathrm{III}_{\mathrm{B}}$ would become more predominant 
than route $\mathrm{III}_{\mathrm{A}}$, leading to much faster phenol degradation. Thus, the EC process at the $\mathrm{Ti} / \mathrm{SnO}_{2}-\mathrm{Sb}$ anode was mainly of the hydroxyl radical mechanism.

In contrast, the low overpotentials of the $\mathrm{Pt}$ and $\mathrm{Ti} / \mathrm{RuO}_{2}$ anodes would shorten the lifetime of the hydroxyl radicals, and hence hinder the oxygen transfer from the radicals for organic oxidation. The reaction steps $\mathrm{I}$ and $\mathrm{III}_{\mathrm{B}}$ would become less important, whereas the slow routes of II and $\mathrm{III}_{\mathrm{A}}$ would be more dominant in the pathway (Fig. 3). Thus, direct elector transfer reactions likely took place at the $\mathrm{Pt}$ and $\mathrm{Ti} / \mathrm{RuO}_{2}$ anodes leading to phenol oxidation. In addition, the $\mathrm{Ti} / \mathrm{SnO}_{2}-\mathrm{Sb}$ anode may have a better affinity with organic substances than the other two anodes. Better adsorption of the organic on the anode surface would improve electron transfer for direct organic oxidation, and allow a more effective indirect oxidation by the hydroxyl radicals generated on the anode.

\section{Conclusions}

Phenol could be readily mineralized at the $\mathrm{Ti} / \mathrm{SnO}_{2}-\mathrm{Sb}$ anode; however, its degradation was considerably slower at the $\mathrm{Ti} / \mathrm{RuO}_{2}$ and $\mathrm{Pt}$ anodes. The intermediate products of EC phenol degradation, including benzoquinone and organic acids, were subsequently oxidised rapidly by the $\mathrm{Ti} / \mathrm{SnO}_{2}-\mathrm{Sb}$ anode, but accumulated in the cells of $\mathrm{Ti} / \mathrm{RuO}_{2}$ and Pt. The surface property of the electrodes appeared to affect the kinetics of various steps of EC organic oxidation. More importantly, the anode could also mediate the pathway of organic degradation. Specific anode surface treatment such as the $\mathrm{SnO}_{2}-\mathrm{Sb}$ coating provided the anode with an apparent catalytic function for rapid organic oxidation that was probably brought about by hydroxyl radicals generated from anodic water electrolysis. However, some anode materials, such as $\mathrm{Ti} / \mathrm{RuO}_{2}$ and $\mathrm{Pt}$, were less favourable for use in the EC treatment of organic pollutants, because of their lack of the EC catalytic capacity and the production of intermediates more refractory to additional treatment. Based 
on the experimental study, a modified reaction pathway of EC phenol degradation was proposed. It is argued that under the electro-catalytic condition at the $\mathrm{Ti} / \mathrm{SnO}_{2}-\mathrm{Sb}$ anode the aromatic ring opening takes place rapidly. Maleic acid formed from ring cleavage can be oxidised directly to oxalic acid that can be readily mineralised by EC oxidation. However, at the $\mathrm{Ti} / \mathrm{RuO}_{2}$ and $\mathrm{Pt}$ anodes without significant catalytic functions, ring breakage becomes more difficult. The accumulation of intermediate aromatic compounds, such as hydroquinone and benzoquinone, will lead to the formation of more stable polymeric products. In addition, maleic acid will undergo a slow EC degradation process involving the formation of a number of intermediate organic acids, including succinic acid, malonic acid and acetic acid.

\section{Acknowledgments}

This research was supported by a grant from the Research Grants Council of the Hong Kong SAR, China (HKU7008/01E), and a grant from the National Nature Science Foundation of China (50278022). The technical assistance of Mr. K.C.H. Wong is highly appreciated.

\section{References}

1. Brillas E, Mur E, Sauleda R, Sanchez L, Peral J, Domenech X, Casado J. Aniline ineralization by AOP's: anodic oxidation, photocatalysis, electro-Fenton and photoelectro-Fenton processes. J Appl Catal B: Environ 1998;16:31-42.

2. Esplugas S, Gimenez J, Contreras S, Pascual E, Rodriguez M. Comparison of different advanced oxidation processes for phenol degradation. Water Res 2002;36:1034-1042.

3. Comninellis C. Electrocatalysis in the electrochemical conversion/combustion of organic pollutants for waste-water treatment. Electrochimica Acta 1994;39:1857-1862. 
4. Rodgers JD, Jedral WJ, Bunce NJ. Electrochemical oxidation of chlorinated phenols. Environ Sci Technol 1999;33:1453-1457.

5. Brillas E, Calpe JC, Casado J. Mineralization of 2, 4-D by advanced electrochemical oxidation processes. Water Res 2000;34:2253-2262.

6. Kötz R, Stucki S, Carcer B. Electrochemical waste-water treatment using high overvoltage anodes I: physical and electrochemical properties of $\mathrm{SnO}_{2}$. J Appl Electrochem 1991;21:14-20.

7. Chiang LC, Chang JE, Wen TC. Indirect oxidation effect in electrochemical oxidation treatment of landfill leachate. Water Res 1995;29:671-678.

8. Johnson SK, Houk LL, Feng JR, Houk RS, Johnson DC. Electrochemical incineration of 4-chlorophenol and the identification of products and intermediates by mass spectrometry. Environ Sci Technol 1999;33:2638-2644.

9. Feng YJ, Li XY. Electro-catalytic oxidation of phenol on several metal-oxide electrodes in aqueous solution. Water Res 2003;37:2399-2407.

10. Stucki S, Kötz R, Carcer B, Suter W. Electrochemical waste-water treatment using high overvoltage anodes II: anode performance and application. J Appl Electrochem 1991;21:99-104.

11. Chen GH. Electrochemical technologies in wastewater treatment. Sep Purif Technol 2004;38:11-41.

12. Simod $\mathrm{O}$, Comninellis $\mathrm{C}$. Anodic oxidation of organics on $\mathrm{Ti} / \mathrm{IrO}_{2}$ anodes using Nafion(R) as electrolyte. Electrochimica Acta 1997;42:2013 - 2018.

13. Feng JR, Johnson DC. Electrocatalysis of anodic oxygen-transfer reactions: Titanium substrates for pure and doped lead dioxide films. J Electrochem Soc 1991;138:33283337. 
14. Houk LL, Johnson SK, Feng JR, Houk RS, Johnson DC. Electrochemical incineration of benzoquinone in aqueous media using a quaternary metal oxide electrode in the absence of a soluble supporting electrolyte. J Appl Electrochem 1998;28:1167-1177.

15. Schumann U, Grundler P. Electrochemical degradation of organic substrates at $\mathrm{PbO}_{2}$ anodes: monitoring by continuous $\mathrm{CO}_{2}$ measurements. Water Res 1998;32:2835-2842.

16. Feng JR, Houk LL, Johnson DC, Lowery SN, Carey JJ. Electrocatalysis of anodic oxygen-transfer reactions: the electrochemical incineration of benzoquinone. $\mathrm{J}$ Electrochem Soc 1995; 142:3626-3632.

17. Tahar NB, Savall A. Electrochemical degradation of phenol in aqueous solution on bismuth doped lead dioxide: a comparison of various electrode formulations. J Appl Electrochem 1999;29:277-283.

18. Tanaka S, Nakata Y, Kimura T, Yustiawati, Kawasaki M, Kuramitz H. Electrochemical decomposition of bisphenol A using $\mathrm{Pt} / \mathrm{Ti}$ and $\mathrm{SnO} 2 / \mathrm{Ti}$ anodes. J Appl Electrochem 2002;32: 197-201.

19. Correa-Lozano B, Comninellis C, DeBattisti A. Service life of Ti/ $\mathrm{SnO}_{2}-\mathrm{Sb}_{2} \mathrm{O}_{5}$ anodes. J Appl Eletrochem 1997;27:970-974.

20. Polcaro AM, Palmas S, Renoldi F, Mascia M. On the performance of $\mathrm{Ti} / \mathrm{SnO}_{2}$ and $\mathrm{Ti} / \mathrm{PbO}_{2}$ anodes in electrochemical degradation of 2-chlorophenol for wastewater treatment. J Appl Electrochem 1999;29:147-151.

21. Comninellis C, Pulgarin C. Anodic-oxidation of phenol for waste-water treatment. J Appl Electrochem 1991;21:703-708.

22. Gattrell M, Kirk DW. A study of the oxidation of phenol on platinum and preoxidised platinum surfaces. J Electrochem Soc 1993;140:1534-1540.

23. Andreescu S, Andreescu D, Sadik OA. A new electrocatalytic mechanism for the oxidation of phenols at platinum electrodes. Electrochem Commun 2003;5:681-688. 
24. Iniesta J, González-García J, Expósito E, Montiel V, Aldaz A. Influence of chloride ion on electrochemical degradation of phenol in alkaline medium using bismuth doped and pure $\mathrm{PbO}_{2}$ anodes. Water Res 2001;35:3291-3300.

25. Li XY, Ding F, Lo PSY, Sin SHP. Electrochemical disinfection of saline wastewater effluent. J Environ Eng, ASCE 2002;128:697-704.

26. Zhang ZX. Technology for Ti-based Electrodes. Beijing: China Metallurgical Industry; 2000. p 233.

27. Shim YB, Park SM. Spectroelectrochemical studies of p-benzoquinone reduction in aqueous media. J Electroanal Chem 1997;425:201-207.

28. Peiró AM, Ayllón JA, Peral J, Doménech X. TiO 2 -photocatalyzed degradation of phenol and ortho-substituted phenolic compounds. Appl Catalysis B: Environ 2001;30:359373.

29. Erbe T, Bruckner H. Chromatographic determination of amino acid enantiomers in beers and raw materials used for their manufacture. J Chromatogr A 2000;881:81-91.

30. Wang GH, Niu SL, Liu C, Wang LS. Identification of dicarboxylic acids and aldehydes of PM10 and PM2.5 aerosols in Nanjing, China. Atmos Environ 2002;36:1941-1950.

31. Peña-Alvarez A, D'ýaz L, Medina A, Labastida C, Capella S, Vera LE. Characterization of three Agave species by gas chromatography and solid-phase microextraction-gas chromatography-mass spectrometry. J Chromatogr A 2004;1027:131-136.

32. Rieger PH. Electrochemistry. Englewood Cliffs, NJ: Prentice-Hall; 1987. p 66.

33. Hagen T, Korson MS, Sakamoto M, Evans JE. A GC/MS/MS screening method for multiple organic acidemias from urine specimens. Clinica Chimica Acta 1999;283:7788. 
34. Gonzalez-Bravo L, Marrero-Delange D, Gonzalez-Guevara JL. Group method approach to the estimation of response factors of unavailable substances in quantitative gas chromatography. J Chromatogr A 2000;888:159-173.

35. Rajeshwar K, Ibanez JG, Swain GM. Electrochemistry and the environment. J Appl Electrochem 1994;24:1077-1091.

36. Mengoli G, Musiani MM. Protective coatings on iron by anodic-oxidation of phenols in oxalic-acid medium. Electrochimica Acta 1986;31:201-210.

37. Lund H, Baizer MM. Organic Chemistry. New York: Marcel Dekker; 1991. p 616.

38. Iniesta J, Michaud PA, Panizza M, Cerisola G, Aldaz A, Comninellis Ch. Electrochemical oxidation of phenol at boron-doped diamond electrode. Electrochimica Acta 2001;46:3573-3578.

39. Kirk DW, Sharifian H, Foulkes FR. Anodic-oxidation of aniline for waste-water treatment. J Appl Electrochem 1985;15:285-292.

40. Simod O, Schaller V, Comninellis C. Theoretical model for the anodic oxidation of organics on metal oxide electrodes. Electrochimica Acta 1997;42:2009-2012. 


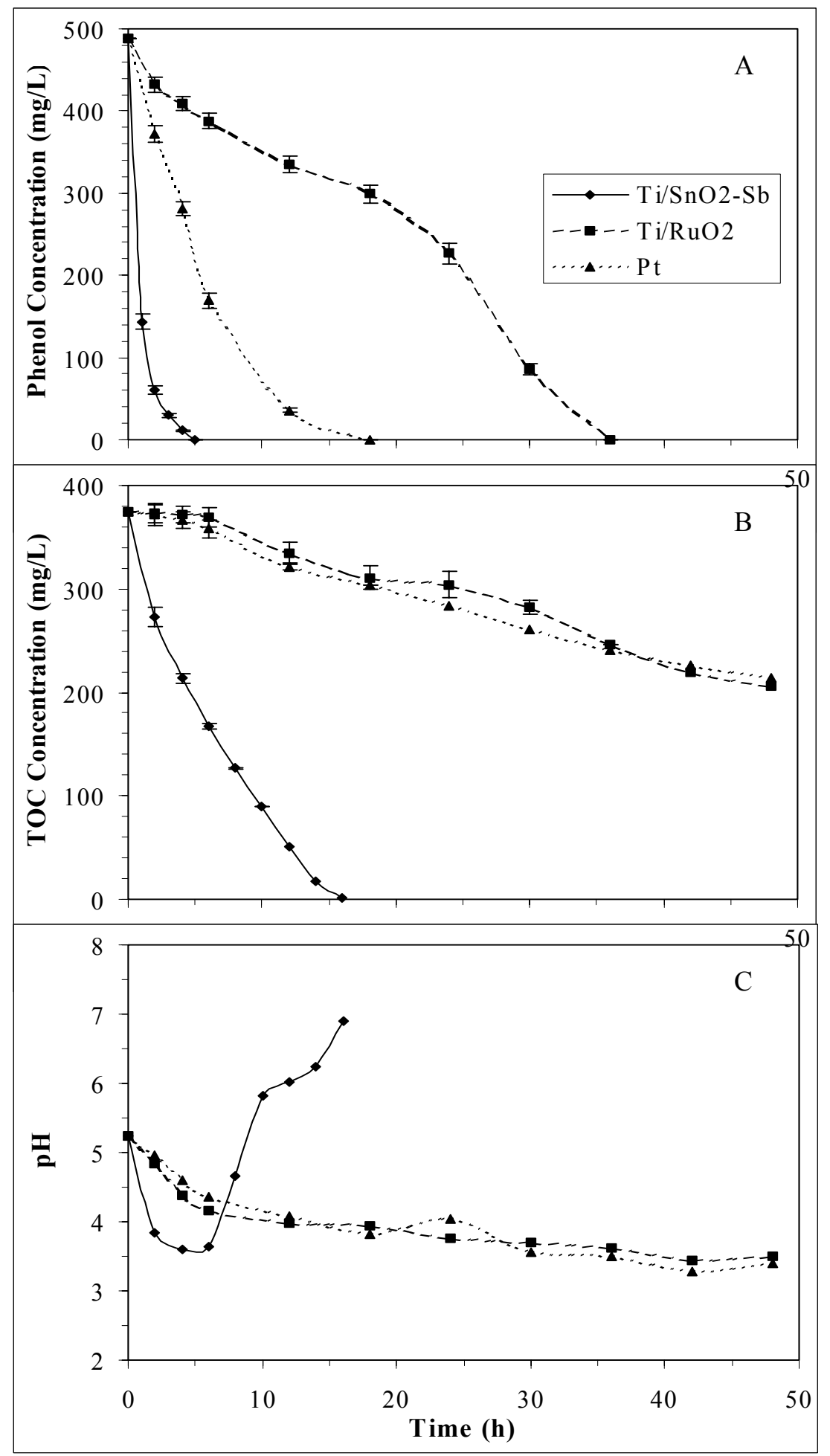

Fig. 1. Electrochemical degradation of phenol (490 $\mathrm{mg} / \mathrm{L})$ on anodes $\mathrm{Ti} / \mathrm{SnO}_{2}-\mathrm{Sb}$, $\mathrm{Ti} / \mathrm{RuO}_{2}$, and $\mathrm{Pt}$ at a current intensity of $20 \mathrm{~mA} / \mathrm{cm}^{2}$. (A) Phenol degradation, (B) TOC removal, and (C) $\mathrm{pH}$ variation. 


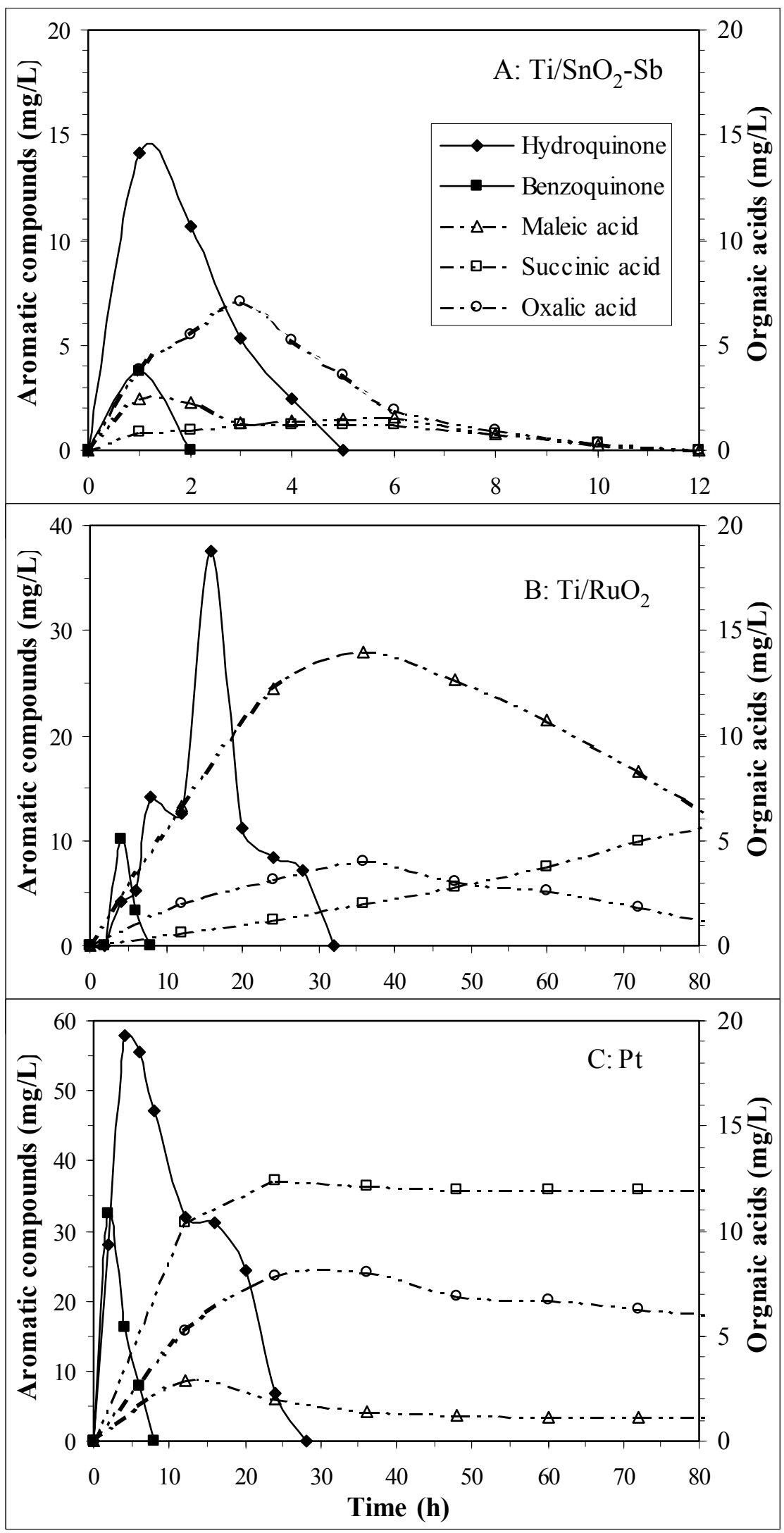

Fig. 2. Intermediate products of EC phenol $(490 \mathrm{mg} / \mathrm{L})$ degradation at a current intensity of $20 \mathrm{~mA} / \mathrm{cm}^{2}$ on anodes (A) $\mathrm{Ti} / \mathrm{SnO}_{2}-\mathrm{Sb},(\mathrm{B}) \mathrm{Ti} / \mathrm{RuO}_{2}$, and (C) Pt. 
<smiles>CCCCCC</smiles>

Phenol<smiles>[O]c1ccccc1</smiles>

Phenoxy radicals<smiles>C=CC1CCCC(=C=C2C=CCCC2=O)C1=O</smiles><smiles>C=[Tl]</smiles>

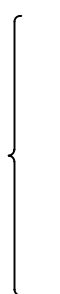<smiles>Oc1ccc(O)cc1</smiles><smiles>C=CCCCCC1=CC(=O)C=CC1=O</smiles>

Hydroquinone Benzoquinone
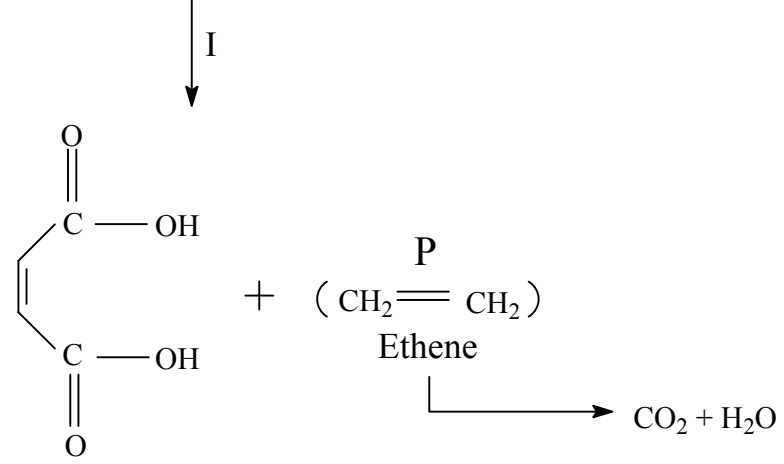

Maleic acid<smiles>CCOC(=O)C(C)(C)C(=O)O</smiles>

Fig. 3. Reaction pathway of electrochemical phenol degradation. 


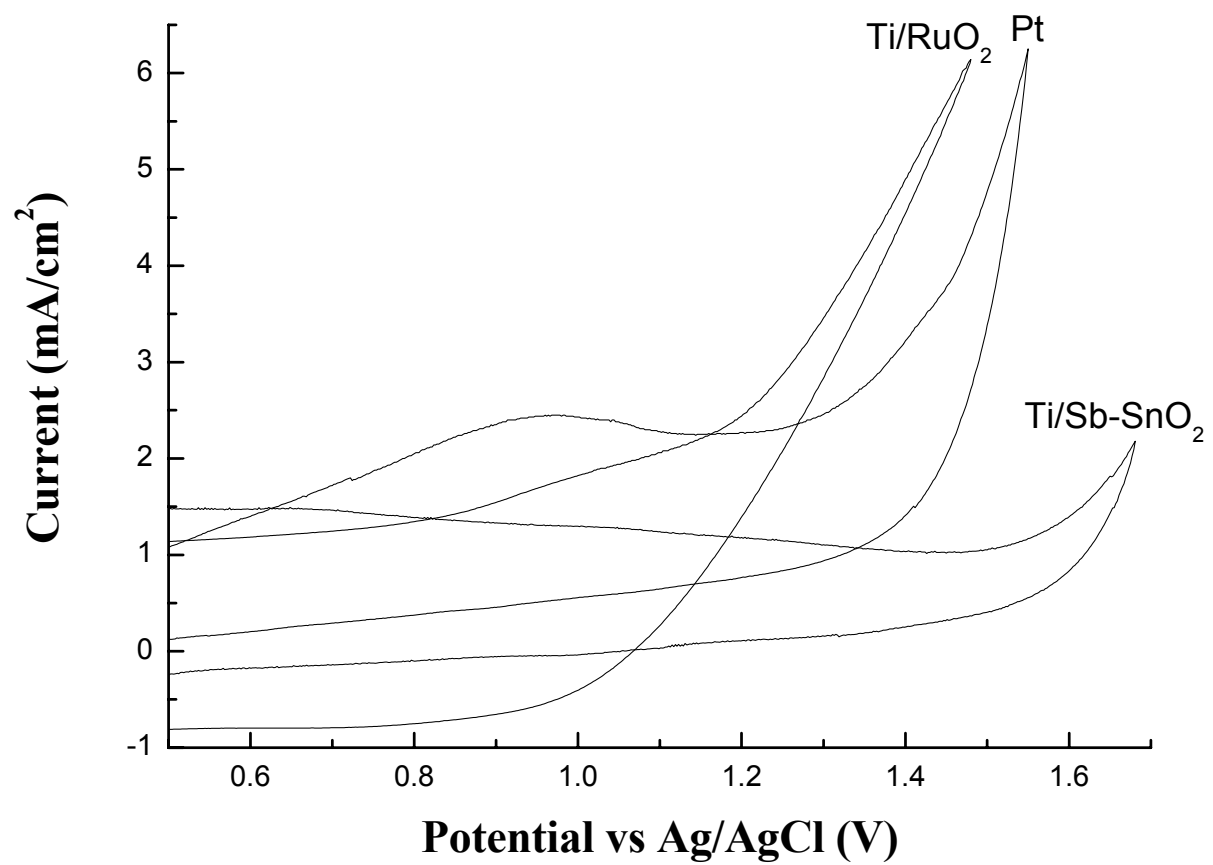

Fig. 4. Voltammograms of the anode materials $\mathrm{Ti} / \mathrm{SnO}_{2}-\mathrm{Sb}, \mathrm{Ti} / \mathrm{RuO}_{2}$, and Pt obtained at a scan rate of $100 \mathrm{mV} / \mathrm{s}$ in $0.25 \mathrm{M} \mathrm{Na}_{2} \mathrm{SO}_{4}$ at $25^{\circ} \mathrm{C}$ and $\mathrm{pH}=6$. 